\title{
Conflict in Private Land: The Role of "Yellow Journalism" in the Turmoil of Batu Ceper, Tangerang 1934
}

\author{
Muhamad Mulki Mulyadi Noor*, Susanto Zuhdi \\ Department of History, Faculty of Humanities, Universitas Indonesia \\ Depok, Indonesia
}

*Corresponding Author: mulkinoor@gmail.com

DOI: https://doi.org/10.14710/ihis.v4i2.8875

Received:

September 5, 2020

Revised:

November 24, 2020

Accepted:

December 1, 2020

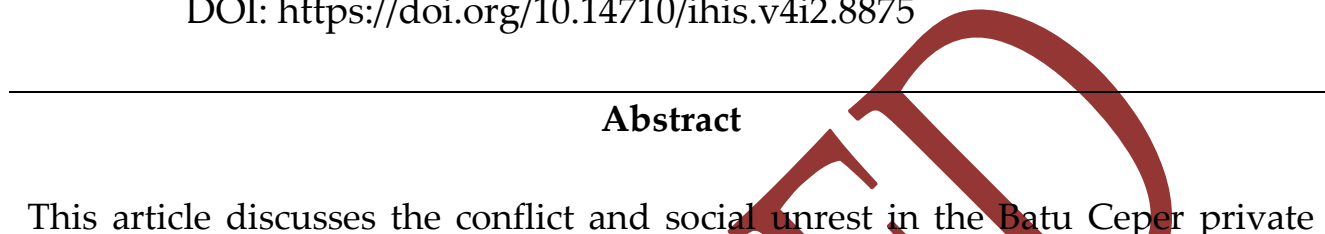

This article discusses the conflict and social unrest in the Batu Ceper private lands. The events in Batu Ceper was an example of anti-extortion movement erupted due to the cuke and kompenian problems against the background of the socio-economic issues since the late 19th century. This study identifies "yellow journalism" concept which succeeded in uplifting the Batu Ceper event with a bombastic and sensational headline in the form of an exciting debate between the newspapers of the landlord's defender (the white press) and the peasant advocates (press Indonesier). The victory of the white press in the court did not mean the end of potential chaos, because the anxiety which became the factor of chaos never faded away due to a mere court ruling. This article reflects the field of social history, in which the study uses mass media as its primary focus. It shows the characteristic of disruption in a historical perspective.

Keywords: "Yellow Journalism";Conflict; Peasants; Landlords; Private Land.

\section{Introduction}

One article in Bintang Timoer newspaper on 4 June 1934 stated that an envoy of the court of Batavia at the request of the landlord came to confiscate the rice of a peasant in Batu Ceper due to the unpaid debt from the force labour called kompenian. This seizure, according to the article, infuriated the peasant who spontaneously tried to grab the rice back from the envoy's hand. Suddenly the number of inhabitants who saw the incident emotionally helps their comrade and came to attack the delegates, and then the turmoil begun with increasing number of angry masses. The police fired salvo into the air to alert the mob. Instead of creating fear, the peasants increasingly pushed forward to take the rice. It forced the Wedana of Tangerang to calm the crowd ("Keriboetan di tanah Batoe Tjeper (Tangerang)," 1934). This case became massively distributed through mass media with some sensational headlines such as keriboetan [commotion], kerewelan [fuss], and conflict met landheer [conflict with land owner] added with provocative phrases like sewa tanah dinaikkan 400\% [land leasehold has been got up], pers putih menghasoet [the white press incited], and Arga in actie [Arga in action]. All of these headlines represented crime and violation of law that came from a baseless allegation. In fact, the incident was occurred only a day or even half a day. 
The news in mass media that focused on the search of 'sensational theme' with topics of riots and criminality is the characteristic of a "yellow newspaper" or popularly known as "yellow journalism". This style of journalism emerged in the late $19^{\text {th }}$ century in the United States. According to Frank Luther Mott, "yellow journalism" contains sensational elements to attract readers such as news about crimes, sex scandals, gossip, and natural disasters. It sometimes accompanied by interviews and false allegations. In addition, Mott also added elements such as political campaign material which accused other party and the tendency to give voice to the victim of injustice in the society. The term was firstly used by the New York Tribune in 1897 to fight popular newspapers such as William Randolf Hearst's New York Journal and Joseph Pulitzer's New York World. Both of these newspapers use the "yellow journalism" style solely to increase sales (Campbell, 2001, p. 7)

In the case of Batu Ceper, the event was exaggerated with sensational headlines and accusations from the pro-landlord newspaper (or white press) to the pro-peasant newspaper (or Indonesier press). The white press stated that Tirtajasa organization was the mastermind behind the riot in Batu Ceper. On the contrary, the Indonesier press stated that it was the landlord who did the ingustice to the people, as the landlord raised the tax by 400 percent. They dismissed the other party that might be involved in the event. The Indonesier press even mentioned that the landlord of Batu Ceper himself was the one who triggered the commotion.

Based on the study in the Indonesian archives, the conflict between the landlord and the peasants was not new in Tangerang. One sprout of conflict actually had risen in Tegalkunir, 1913. This conflict was originated from a case of fighting between a child of "Pribumi" or indigenous and a Chinese child. This incident led to the killing of Gudel, the father of the indigenous child by 'thugs' of the landlord in that area. On the following day after Gudel's burial, one of Gudel's son Sailan intended to take his father's pile of rice on the scene. Seeing blood stain on the pile of rice that might belong to his dad, Sailan became mad. Together with several other Peasants, Sailan chased and killed one poon Chinese who accidentally just passing on the street (Kartodirdjo, 1981, p. xxvii). Another sprout of conflict can also be seen in the incident of Serpong in 1917. Warsid, a native of Serpong, led the peasants to object against the rise of tax. They protested the court's decision to win the landlord over the Cuke problem. At that time, many peasants gathered on the street to join the protest. The police and local officials were then involved in the process to calm the peasants. In the end, the conflict was successfully evaded ("Proces verbaal", 1917, Tangerang Collection Archive No. 106.5).

So far, the biggest case of conflict involving community leaders in Tangerang was the Kaiin Bapa Kayah Movement (1924). It was led by a puppeteer (dalang) named Kaiin Bapa Kayah who spread the movement to reject the Chinese landlords who were considered usurper to the ancestral lands of the indigenous people in Tangerang. Kaiin Bapa Kayah tried to convince his followers to expelled all Chinese from Tangerang land (Kartodirdjo, 1978, p. 48). But although it was a big event in Tangerang, Kaiin 
Bapa Kayah movement was not organized. Thus, it can be easily be annihilated by the colonial police.

Previous studies describing about the peasant's protest in private lands has been widely discussed by several researchers such as Kartodirdjo (1978), Iskandar (2007), Anwar (1990), Imaduddin (2015) and Ilyas (2016). All of the works mentioned here agreed, by referring to Kartodirjo's thesis (1978), that the private land system tended to incriminate the peasants. In particular, it was due to the policies of the landlord that were inconsistent with the prevailing reglement (government regulation) so that it could easily ignite riot and protest from the peasants. Given this situation, a little provocation or small 'assistance' from outside the peasant community could help to start a conflict. However, these studies pose different view in determining the character of the movement, albeit many are still referring to the categorization by Kartodirdjo (1978) regarding the anti-extortion movenent, Messianism, Revivalism and Sectarianism, and the local branch of Sarekat Islam (Kartodirdjo, 1978). Based on these characteristics, this study examines the events in Batu Ceper as an anti-extortion movement carried by a movement outside of Sarekat Islam, because during 1930s, the influence of Sarekat Islam had already been weakened. The organization that focused on empowering peasant communities in private land at that time was Tirtajasa organization. Tirtajasa moved through raising awareness activities and legal education to peasants in the villages.

In addition, mass media involvement in the conflict of private land is also a rather new phenomenon. It had happened since the late $19^{\text {th }}$ century newspapers in the Dutch East Indies experienced rapid developments with the emergence of various newspapers published by various institutions, from the indigenous, the Chinese and the European. Therefore, the main focus of this study is to explain how did the incident in Batu Ceper happened by examining the writing style of the newspaper regarded as "yellow journalism" that might have a role to herald public opinion and create sensational news for the event. I hope that this article will contribute to the study of social history with regards to the protest of colonial peasant, especially the role of the press. In historical context, such phenomenon is the marker of the emergence of 'disruption era". Strengthening Kartodirdjo's thesis, social movement of the peasants did contribute to the birth of Indonesian proto-nationalism.

\section{Mass Media and Social Movement}

Regarding the term of social movement, Kartodirdjo emphasizes the difference between traditional movement that occurred in $19^{\text {th }}$ century and what happened in the modern era which the idea of emancipation and the national awareness had penetrated the public imagination and also created a new dimension in which the organization became strong factor that distinguished between these two type movements (Kartodirdjo, 1978, p. 17). Moreover, the influence of mass media over the social movement in modern era is crucial to maintain public opinion. Thus, this article tries to use the media studies approach by using "hypodermic needle theory". It is a theory developed in the late $19^{\text {th }}$ century. This theory stated that the mass media has 
full ability in influencing public opinion, because the audiences passively receive news without questioning it again. This theory is developed in relation to the role of media as a tool for propaganda in the first world war. It was named as the "theory of a needle" or "bullet theory" because media was able to convey a message directly to the readers effectively (Rakhmat, 1989, p. 83-87).

The method used in this study is a historical method, which is a process of critically examining and analyzing past recordings and relics about the conflict between peasant and landlord in Batu Ceper. Then the important points that have been analyzed are then written or presented in accordance with the shape, events, atmosphere and duration of the related historical research topics (Gottschalk, 1986). This study is a social history which describes Batu Ceper as a debate arena between the two presses (white press and the Indonesier press). Therefore, it uses both primary and secondary sources, such as books, journals, newspapers and archivers. Some Dutch-language newspapers are accessible online, such as delpher.nl website, while Malay-language newspaper archives such as Sin Tit Po, Keng PO, and Bintang Timoer, can be accessed at the National Library of Indonesia. It was found that newspapers were the main source of this research while further research based on colonial archives needed to be done.

\section{Mass Media Impact on the Private Land}

This study shows that mass media, both pro-landlord and pro-peasant, gave full attention to the conflict in Batu Cepen The pro-landlord (white press) was represented by Chinese-language Malay newspapers such as Keng Po and Sin Tit Po as well as Dutch-language newspapers such as Soerabaiasch Handelsblad, Het Nieuws van den Dag voor Nederlandsch Indie, Bataviaasch Nieuwsblad and others, while the pro-peasants were represented by Bintang Timoer. In otherwords, the incident in Batu Ceper private land in 1934 was an event that came outy of the boundaries of its locality not only in the scope of the eventitself. The issues that were raised became very attractive and directly related to the newsreaders on both sides. This case was of concern to the public thanks to the ability of important figures and organizations who were considered the masterminds of the incident to spread opinions through the mass media.

Moreover, the "yellow journalism's" sensational publications were also quite dramatic asobserved from the debates in the news media. The white press represented by Dutch-language newspapers and Malay-speaking Chinese newspapers supported the landlords as part of law enforcement that prevailed at the time. The white press even tried to bring down the reputation of the side which defended the peasants. Similarly, the Indonesier press tried to overthrow the landlord's reputation by using high tax issue. The press in colonial society according to Kartodirdjo, was the representation of public criticism and also an influential means of opinion. It serves as a tool that provides publicity with good effects (Kartodirdjo, 1984, p. 17).

The study also agrees that the peasants who usually remain passive were actually unable to carry out the rebellion without a 'strong cause'. But, because rice, which was the basic necessity for the peasant, was being deprived, they would of 
course become angry and thus rebelled (Iskandar, 2007, p. 16). Another factor is the solidarity of the peasants in helping their comrades. The effort of the Police to prevent further disturbance and chaos were ignored by the masses. This situation was an accumulation of the peasant disappointment for several years. Although the landlord denied about raising taxes, the Indonesier press tried to prove that the landlord should also be responsible for the situation. According to the Indonesier press, this situation made the people became nervous and they quickly felt that they were offended by the landlord. It is an indication that the reputation of the landowners of Batu Ceper had decreased during this time.

\section{History of Batu Ceper Private Land}

In this study, Batu Ceper was a private land (particuliere landerijen) that located in the eastern part of Tangerang. According to the Topografische Inrichting (Topographical Establishment) map (1910), the west of Batu Ceper was adjacent to Parungkoeda, to the east by the land of Kalideres and Burgvliet. The border of Batu Ceper in the north was Selapanjang Oost and Kamal of Tegalaloer and the border in the south was Tanahtinggi and Poris. Batu Ceper was very strategic because it was close to the railway line through Tanahtinggi. Geographically, it was quite close to the main road into the city of Tangerang (as it is indicated in Figure 1).

In 1867, the district of East Tangerang had about 61 private lands. Batu Ceper private land had about 2,043 bau $\left(1\right.$ bau $\left.=7096.5 \mathrm{~m}^{2}\right)$ Batu Ceper had seven villages with a population of 2,791 natives and 375 Chinese (Ekajati, 2004, p. 126). In the 1930s, apparently, Batu Ceper's private soil expanded to about 2,085 bau with a total population of 4,440 people, which means that it increased almost twice than the previous number of population (Regerings almanak voor Nederlandsch-Indie, 1930).

Batu Ceper had been sold to private party in the beginning of $19^{\text {th }}$ Century. The first landlord of Batu Ceper was C.H Specht, the European who bought this land in 1808 and continued under several ownership until Chinese Lieutenant named Tang Tian Po bought it in 1869 (Noor, 2019, p. 4). The ownership of this land was later inherited by Tan Tiang Po's son named Tan Liok Tiauw (Regerings almanak voor Nederlandsch-Indie, 1869). In 1897 Tan Tiang Po established a family company under the name N.V Cultuur Maaschapij Batoe Tjeper with a capital of two hundred thousand guilders in which the Tan family built a brick and tile factory (Handboek voor cultuur en handelsonderneningen in Nederlandsch-Indie, 1926, p. 76). Tan Liok's tile production was used in the important buildings in Batavia, including the second building of the Nederlandsch-Indische Escompto Maatschapij completed in 1928 (Ade Mulyani, 2011, p. 49). In addition, the success of this company was evidenced by the visit of the Netherlands Indies Governor General Dirk Fock to inspect the factory in Batu Ceper in 1923 (“De gouverneur-general," 1923, p. 23). 


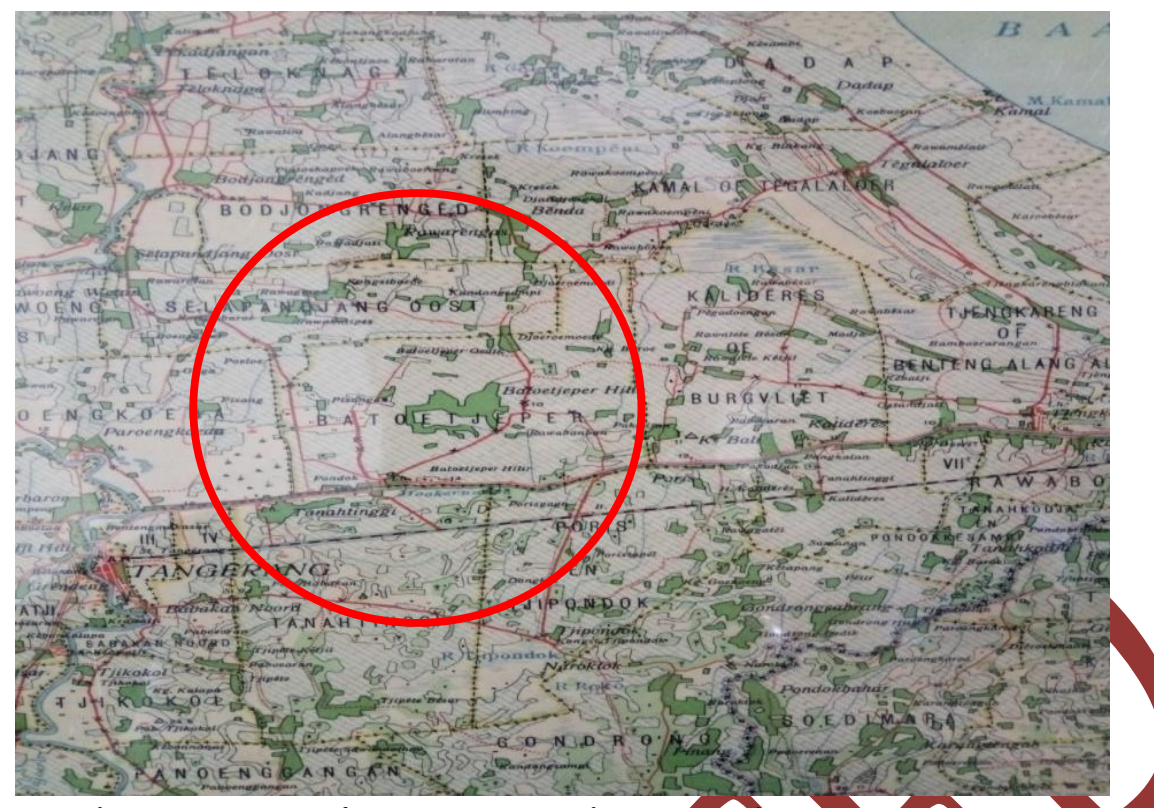

Figure 1. Map of Batu Ceper Private Land, East Tangerang.

Source: Tangerang, Topografische Inrichting Batavia, 1910.

In 1917 Tan Tiang Po also established a plantation company under the name Tan Tiang Po Landbouw which advanced rapidly under the maryagement of his son Tan Liok Tiauw. Until 1933, this company was able to control several private lands such as Rawa Buaya, Tanah Koja, Pondok Kosambi, Minggu Jawa and Kapuk. All these territories were located between Batavia and Tangerang (Regerings almanak voor Nederlandsch-Indie, 1933). These private lands produced commodities such as crops, rice, peanuts, tobacco and indigo. Particularly in Batu Ceper which in 1912 produced tobacco. In 1916 Batu Ceper did not produce any more tobacco, the remainings were rice, peanuts, indigo and yams with an annual tax income of 187,000 guilders (Regerings alntanak voor Nederlandsch-Indie, 1916).

Although Batu Ceper had experienced its heyday until the early 1930s, Batu Ceper's private land was in fact suffered by internal and external problems. Internal problems, including Tan Liok Tiauw indicted murder's case. The Tangerang District Court in 1903 decided to mprison Tan Liok Siauw with his accomplice namely Tahir with chain punishment and forced labor for 20 years ("Gemengd Indisch nieuws," 1903), but Tan Liok Tiauw then appealed to a higher court, the High Court of European and Eastern Foreigner Affairs (Raad van Justitie), who eventually released Tan in January 1904 for the lack of evidence ("De moordzaak van Batoe Tjepper," 1904).

While external problems came from several crimiminal cases, population protest concerning taxes in previous years and the government's desire to buy back private land grew stronger. After incident in Batu Ceper, one Malay-language newspaper tried to attack Tan Liok Siauw personally by questioning why Tan, who had been convicted of the murder case, was strangely acquitted by Raad van Justitie. The newspaper also highlighted Tan's inability to maintain a security in his teritory that there had been two cases of peasants' murder that were not clear who the perpetrators were ("Keriboetan di Batoe Tjeper (Tangerang)," 1934c). The report also criticized Tan Liok Tiauw's capricious behavior. It also explained the injustice that Conflict in Private Land: The Role of "Yellow Journalism" in the Turmoil of Batu Ceper, Tangerang 1934 
occurred in the private land regulation system that was very pro-landlord. According to the report, the criminality that occurred indicated the inability of the landlord and his apparatus in maintaining security which caused prolonged anxiety in society.

On March 24, 1937 the government finally decided to buy the Batu Ceper land at a compensation of 365,000 guilders ("Het land Batoe Tjeper," 1937). Although it was said that this purchase was important for the reconstruction of irrigation in Tangerang, this seemed to be the reason for the government to immediately end the private land system in Batu Ceper as well as to put an end to the disturbances in the area during the 1930s. Therefore, the area of Batu Ceper was returned back to the colonial government's property.

\section{Particuliere Landerijen and Its Problems}

Regarding the term particuliere landerijen (private land), Iskandar in his dissertation described that it was the private land which derived from the practice of the VOC to sell its land until about 1820s. It was not only the regulation of the land acquisition but also, the regulation to manage the people who live in the region. The owner of Particuliere landerijen was usually received various privileges from the VOC such as the right to take any cash crop product of the peasant in the area and also to use forced labor called Kompenian (Iskandar, 2007, p. 26).

The impact of those obligations is that the peasant became poor due to heavy demand to pay many taxes and also force labor in theiy everyday life. In other word, as suggested by Kartodirdjo, the pressure from work made the life of the peasant suffered badly (Kartodirdjo, 1978, p. 197). Useful explanation about the oppressed peasant can also be found in J.H Kievits journal published in 1890, who wrote that somewhere in Batavia, not far from Karawang, there was a large particuliere landerijen whose inhabitants were opressed in such a way that it made humane to creeps (Tjwan, 2008, p. 74) Moreover, if the peasants refuse to do Kompenian or fail to pay the taxes, they willbe pressured and persecuted by the Jawara or Centeng (subordinates of the landlord) or being prosecuted by the landlord in the court (Ekajati, 2004, p. 130). According to the report by the Resident of Batavia in 1934, the amount of taxes in the particuliere landerijen needed to be lowered by the government because it was too much for the population (Kartodirdjo, ed., Memori Serah Terima Jabatan, ANRI, 1978). It tells us that the high taxes also alarmed the government official.

This situation is called by Smelser as "Social Conduciveness" which became one prime element to cause protest or movement. Social condition that supports this cause would then enable the "Structural Strain" to rise (Smelser,1981, p. 15). This, in fact may refer to the private land system which being regulated in the 1836 . The system was revised in 1912 ("Reglement omtrent de particuliere," 1836; 1912). Although the new system was 'better' to explain the right and the obligation between the peasant and the landlord, many problems still occurred because because the government did not have direct control in the private land (Iskandar, 2007, p. 58).

Before 1913, there was no report of social unrest in Tangerang. In relation to this situation, I suggest two possibilities, it was whether the peasants were satisfied with 
the leadership of the landlord or indeed there was no written report mentioning the existence of protest. Perhaps the Chinese landlords tried to avoid any conflict with the peasant in their area after the incident in Ciomas (1886). However, after the enactment of a new reglement in 1912, the incident in Tegalkunir (1913) which coincided with several other protests on Batavia and its sorrounding seemed to surprise many parties because it disrupted the previous harmony between the landlord and the peasants in Tangerang. This case also seemed to put the Chinese as the 'accused party' because of their disrespectful attitude toward the indigenous people during these conflicts. It also bring forth the question about the view and the treatment of the Chinese to the indigenous population before the conflict.

On the other hand, the indigenous economic resistance which was hosted by Sarekat Islam (SI) in 1912 became widespread and uncontrollable, along with the expanding influence of the SI to Tangerang. Moreover, another problem as written in article 54 of the regulation 1912, landlord had the right to bring the issue of unpaid tax and Kompenian to the court to seize the peasant's property as set forth in article 29 ("Peratoeran baroe atas tanah-tanah," 1912). Before 1912, heavy punishment or violence for the offender was common such as drying them in the sun and soaking their bodies in animal feces. (Iskandar, 2007, p. 92).

In fact, the Chinese gained control over the majority of the existing private land in Tangerang. It seems that the Dutch government also forbade the Chinese to assimilate with the indigenous population. Actually, after the Chinese massacre of 1740, Chinese movement had always been a serious concern for the VOC. In 1816 the Dutch government required the Chinese to obtain travel permit which continued with the urge for the Chinese to live in certain part of the city in 1856 (Mely G. Tan, 1979, p. xiii). This discriminatory policy was the cause of the 'Chinese problem' in the private land. The anti-Chinese movement in Tangerang was proposed by Kaiin Bapa Kayah who saw the suffering of the people in the private land. Kaiin's idea to "expel all Chinese back hame" gained many followers. In the other word, as proposed by Smelser (Smelser, 1962, p. 16) the movement was responsible to spread a kind of 'stereotype' among the Indigenous to have prejudice against the Chinese who were regarded as "the other" or "the minions of the Dutch invader" (Ravando, 2014, p. 116).

\section{Course of Turmoil}

On Monday 4 June 1934 around one o'clock, two bailiffs (deurwaarder) from Landraad Batavia came with an assistant of Wedana (senior officer) from Cengkareng to confiscate the rice (beslag) belonging to a peasant of Batu Ceper named Inang bin Limun. The reason was that Inang did not pay the land rent from 1932. Besides, he and his wife named Pentil and his children named Usman also did not pay Kompenian debts from 1933 to 1934 which was postponed because the landlord seemed to expect the peasant to pay the debt for some time. However, because they refused to pay 20 cents per day to replace the Kompenian, the landlords reported them to Landraad as an example to the rest of population ("Itoe keriboetan di Batoe Tjeper,", 1934d). 
Previously, Mr. Assistant Wedana of Cengkareng called Raden Djajoesman, a Wedana of Tangerang to inform him that there would be a beslag in Batu Ceper this afternoon. Mr. Assistant Wedana also informed Raden Djajoesman that there were four policemen guarding the seizure process led by police commander Vorsterman van Ooijen. According to the custom at that time, when the seizure of rice was to be done, the pile of rice was first being weighed. After that, some amount would be taken as a tax under this category: one fifth for the landlord, two fifths for the cutter of the rice. The remaining two fifths were left for the owner of the rice, but, after all the tax bills were deducted, the remaining rice would also be taken upon request of the landlord. Suddenly, Inang was in rage. The rice was taken back by Inang in anger. Then there was an episode of pushing and pulling between Inang and the Mandor (head of program) named Iming together with an employee of the landlord named Tihoel and Mail who were about to transport the rice to the cart ("Keriboetan di tanah Batoe Tjeper (Tangerang)," 1934c; “Conflict met landheer," 1934).

The seizure of the rice was apparently provoked other peasants who saw the incident. It angered the peasant because the band also confiscated Inang's rice. The residents did not know that the seizure was a conservatoir beslag (prejudgement attachment), the confiscation of property of the person who could not pay the debt to other person. Regarding this matter, Mas Arga believed that the seizure of rice owned by Inang was unfounded because the landlord capriciously seized the family's living for one season. Mas Arga wrote:

Keriboetan itoe oleh karena dorongan dari pihak yang membeslag padinya Inang, padi mana jang baroe sadja dapat memotong dan oentoek sangoe penghiduoepanja di satoe moesim sesanak familienja... (Keriboetan di Batoe Tjeper (Tangerang), 1934c) [The Commotion due to encouragement from those who confiscate rice belong to Inang, where he had just be able to aut (paddies) for his family livelihood in a season]

Looking at this chaotic situation, the police then shot salvo to the air three times as a waming for the crowds to disband themselves. However, instead of disbanding, the angered Peasants became more in numbers (about 800) to go forth trying to attach the bailiffs as well as to take back the rice. The chaotic situation subsided after Raden Djajoesman tried to calm the situation by giving explanations to the peasant. After being advised by Wedana, another person named Mr. Moehamad Noer of the Batavia District Council came to explain again why the Inang rice should be confiscated, because the inhabitants wanted to know for themselves on the subject matter. After it was clear that the seized rice was conservatoir beslag of the previous Inang's debt, the residents dispersed. The property of Inang was then entrusted to a local Chinese businessman (Bintang Timoer, 6 June, 1934). The case would be brought to Tangerang court on June 18 to determine whether the seized rice was valid or not.

\section{"Yellow Journalism" in Batu Ceper}

In relation to the chaos in Batu Ceper, according to Indonesier newspapers, several white press such as Javabode, Bataviaasch Nieuwsblad, and Het Nieuws van den Dag voor Conflict in Private Land: The Role of "Yellow Journalism" in the Turmoil of Batu Ceper, Tangerang 1934 
Nederlandsch Indie reported that until today there was no problem at all when the resident's debt was billed by the landlord who wanted to cut the rice. Only after a man named Mas Arga created an incitement in Batu Ceper then the peasants became brave to protest (Bintang Timoer, 1934). Mas Arga was a former native marine with a corporal rank, he also worked as an editor in various newspapers and magazines such as Mimbar Sarekat Islam, Bintang Timoer, Oetoesan Hindia, Bumi Melajoe, and the News Agency called Het Indonesische Pers Agenschap (HIPA) ("Inlandsch journalist naar Digoel," 1929). According to pers-putih, Mas Arga was described as a journalist, nationalist and a pokrol-bamboe, a lawyer who had no legal education. The rise of the practice of pokrol-bamboe in the Indies era was mentioned in Algemeen Handelsblad newspaper. The term pokrol came from the word procureur which means lawyer. The addition of bamboo in the word pokrol derived from the type of bamboo in Java called apus meaning "ngapusi" in the Java language which means cheating or lying. So, the meaning of this term is a lawyer who likes to cheat, behave shrewdy and cleverly tossing facts. To give a professional impression, they always wear after the "nyeleneh" in the form of a suit, blangkon solo, scarf, Tangerang hat and canvas shoes complete with rattan cane. This pokrol-bamboe was usualty hired by landlords to defend them so that this profession was always hated by the local ("Pokrol-bamboe in de desa", 1913).

In contrast with this explanation, this 'bad term' actually was used by the white press with the aim of dropping the reputation of Arga. In addition, according to information circulating secretly, Arga traveled to Tangerang to meet the residents to spread propaganda against the landlords. The article of the white press in Soerabaiasch Handelsblad openly proyoked the govemment to ârrest Arga by writing:

Men mag alleen hopen, dat dit proces aanleiding zal zijn voor de overheid om dergelijke onruststokers als Mas Argate etimineeren ("Batoe Tjeper: Belangrijke", 1934). [We can only hope that this process will be a reason for the government to eliminate such troublemakers as Mas Argal.

Therefore, Mas Arga began to defended himself with a provocative headline: "Chaos in Batoe Tjeper: Lease of Land raised 400\%, White Press Cheats", in his writing Mas Arga criticized the landlord policies in Batu Ceper. He wrote that actually before the turmoil, in the early 30s, there had been many peasants unrest in the area. These protests occurred not because of the behavior of the residents, but it came from the landlord who burdened the population with high taxes. Arga stated two proofs as an example, that the landlord raised the cost of renting the land for a mere peasant named Pari. Previously the land cost 2 guilders and then it was raised to 10 guilders. Another proof of his statement was the land rent of a peasant named Saidi Wain. Previously the land tax cost 5 guilders then it was raised to 25 guilders, whereas in the government-owned land (landsdomein) the land rent tax was reduced by 40 percent. Arga also criticized the landlords who did not comply with the applicable law, i.e. collecting rent money to peasants before the rice was cut. Whereas according to regulation 1912 article 18a mentioned that to cut rice need not ask permission but enough with notification maximum 8 days before cutting time ("Keriboetan di Batoe Tjeper," 1934). 
Later in the same newspaper, Arga again wrote an article entitled "Chaos in Batoe Tjepper (Tangerang): The Bad Side of the private land" dated June 11. Firstly, Arga criticized the complaints filed by Tan Liok Tiauw to Landraad in 1934. It stated that there were already 300 Batu Ceper residents who faced the court for not being able to pay the debt. He also refuted the allegation of the white press about him as the mastermind of the incident by writing that he came to Batu Ceper as a representative of Tirtajasa in order to awaken the rights and obligations of peasants in private land. Arga wrote:

“...sebabnja keriboetan itoe, jaitoe lantaran hasutan Arga. Padahal Arga dalam keriboetan tidak mengetahui apa-apa, dalam vergadering-vergadering Tirtajasa dalam tanah-tanah particulier, ia menerangkan bahwa rakyat pendoedoek tanah particulier wadjib membayar koempenian dan sewah tanah begitoe djoega tjoekai" (Bintang Timoer, 11 Juni 1934)." [...the cause of the commotion was due to Arga's incitement. Even though Arga in the commotion did not know anything, in every Tirtajasa meetings, he always explained that the people of the land were obliged to pay Kompenian and the land rent as well as Cuke.]

Unfortunately, Arga allegations were only partially answered by the landowners as published in Sin Tit Po on 19 June. The administrators only answered the question of tax increase, that there were actually two kinds of taxes regulated in the reglement year 1912 no.422, namely Grondhuur(land rent tax) and Tuinhuur (garden lease tax) i.e. trees, fruit trees or other trees that generates money. For Grondhuur, the landlord should not raise the rent, but for Tuin wuur the landlord did not have the right as stated in article 17 paragraph 16 ("Peratoeran baroe atas tanah-tanah," 1912). If the rent was considered to increase, it was the value of trees and fruits that were increasing every year depending on the income earned by peasants from the garden. According to the landlord, in 1931 there had been a resident of Batu Ceper who reported this to the Tangerang Resident Assistant Mr. Vronk who later came to explain to the population that the increase was in addition to the income from the trees ("Itoe kerewelan di tanah Batoe Tjeper," 1934).

Therefore, because Tirtajasa organization was cornered by the white press, in its pleading Kirtajasa insisted on rejecting Keng Po's June 15th provocative headline entitled "Beladjar Bikin Hoeroe Hara". Tirtajasa stressed that every meeting or vergadering of Tirtajasa was never out of the law. Tirtajasa also explained that Arga was not at all guilty for obeying the provisions outlined by Tirtajasa. Moreover, Tirtajasa stated that a balanced reciprocal relationship as a form of compliance with the law was essential to ensure security especially in private land. This assurance was always delivered in every meeting that also attended by the commissioner from the government, thus if there was a mistake it would certainly be reported or reprimanded ("Tirtajasa di dalam tanah," 1934).

Tirtajasa's involvement in peasant's life in private lands began in the early 1930s. Tirtajasa was an organization of Bantenesse based in Bandung but has branches in many areas including Tangerang. The organization was politically concerned about peasant empowerment in private lands. Besides, Tirtajasa was also interested in 
cultural and artistic activities ("Kesenian: Toneel opvoering," 1934). Perhaps the activities caused a lot of suspicion for Tirtayasa. For instance, one report stated that in the congress of the Union of Indonesian Political Independence Association (PPPKI) in April 1930, one of Tirtajasa's representatives asked the congregation leader how it was possible for peasants to rebel if they did not have weapons, and in such cases how the rebellion should be formulated (Bloembergen, 2011, p. 367). Thus, Tirtajasa had always been regarded by the white press as a nationalist political association sheltering behind the empowerment of the peasant.

Moreover, Arga's involvement in the peasants protest also continued in Landraad [land council]. The trial of the case was held on 18 June 1934 in Tangerang. According to Het Nieuws, this court attracted about 1000 attendees from around Batu Ceper. The landlord was defended by a Dutch lawyer named Mr. Baron van Ittersum while the peasant was defended by Mas Arga as pokrol-bamboe. Meanwhile, among the population many arguments stated that the seizure of rice would be considered invalid. The trial was held long enough by presenting testimony of witnesses from both parties. After weighing the statements of the witnesses, the courtdecided to win the landlord, so the seizure of rice became vatid. The writer of an article in Het Nieuws analyzed that although the court's decision had at least been able to enforce the law, it would most likely bear unpredictable risk due to the decision of the trial which was considered unfair for the indigenous population ("Batoe Tjepper: Belangrijke," 1934).

The turmoil was in fact a smal event but then triggered a reciprocal argument in the mass media that featured a sensational title that contained allegations that had not been proven. It is not clear how the fate of Mas Arga in the end. Although, the later news related to Arga's activity after Batu Ceper incident was his continuation of "pokrol-bamboe's activity" as Het Niews reported in 1936 that Arga defended Tjitra bin Kidang and Wirga, the residents of Tanjung Priok who accused of being involved in violence against someone from Semarang (Noor, 2019, p. 99). Despite being small event, Batu Ceper' case became an issue among Volksraad's member. Therefore, in August 1934, Otto Iskandar DiNata uplifted this event by criticizing the Government's omission regarding the hard life of the resident in Private Lands in his speech at Volksraad's Assembly (Noor, 2019, p. 86).

\section{Conclusion}

The discussion of a conflict in media that reported about conflict between peasant and landlords in Batu Ceper did not occur without any cause behind it. The role of mass media in this case became crucial to scrutinize this problem. It is clear that the involvement of Mas Arga and Tirtajasa in this incident was exploited by the white press to discredit Tirtajasa organization. The latter used this opportunity to express critics and opinions to defend the peasant. The issues raised by the Indonesier press include the issue of the conspicuous increase of tax to discredit landlord and the private land system created by the colonial government. Moreover, the Indonesier press also criticizes the governments for allowing social and economic injustice to prevail in the private land, especially in Tangerang. 
In fact, the newspapers that reported this incident are partial "yellow journalism", because some elements of it could be found in the reports about gossip, crime, natural disaster or war, also in the allegation or sensational titles of the report of this incident. In addition, there was also different perspective and sometimes ideological reason behind the use of such sensational titles for news report of the incident. It could not be separated from the heavy disagreement between the colonial government and the nationalist movement at that time.

Historically, the era of disruption always rises in the context of social and political change in a society. A chaotic or disruptive situation arises when the government institution could not enforce and closely follow by the society. Pax Nederlandica, a colonial order of government, which declared its dominion all over the archipelago in the early twentieth century is questioned here. Various resistances explained in this study shows disruptive situation in the Netherlands Indies. The resistance to Pax-Nederlandica occurred because of the social movements of the colonized peoples against the enforcement of power. Disruption ere in the history of Indonesia during colonial times often marked the emergence of the state of disorder in the society.

\section{References}

Adi, W. (2010). Batavia, 1740: Menyisir jejak Betawi. Jakarta: Gramedia 2010.

Anwar, A. (1990). Gerakan protes petani Bekasi 1913: Studi kasus awal masuknya Sarekat Islam di Tanah Partikelir. Skripsi, Universitas Indonesia

Batoe Tjeper: Belangrijke principieele uitspraak. Landheer in het gelijk gesteld. (1934, June 22). Soerabarasch Handelsblad.

Batoe Tjepper: Belangrijke principieele uitspraak. Landheer in het gelijk gesteld. (1934, June 20). Het Nieuws van den Dag voor Nederlandsch-Indie.

Bloembergen, M. (2011). Polisi zaman Hindia Belanda: Dari kepedulian dan ketakutan. Jakarta: Kompas.

Campbell, W. J. 2Q01). Yellow journalism: Puncturing the myth, defining the legacys. London, Praeger Publisher.

Conflict met landheer. Opstootje op het particuliere Land Batoe Tjeper in het Tangerangsche.(1934, June 9). De Sumatra Post.

De gouverneur-general naar Tangerang. (1923, July 20). De Sumatra Post.

De moordzaak van Batoe Tjepper. (1904, January 19) Batavia Nieuwsblad.

Ekajati, E. S. (2004). Sejarah kabupaten Tangerang. Tangerang: Pemerintah Kabupaten

Tangerang.

Gemengd Indisch nieuws. (1903, Novemer 16). Soerabaiasch Handelsblad.

Gottschalk, L. (1986). Mengerti sejarah. Trans by Nugroho Notosusanto. Jakarta: Penerbit Universitas Indonesia.

Handboek voor cultuur en handelsondernemingen in Nederlandsch-Indie. 1926. Amsterdam: De Bussy.

Het land Batoe Tjeper. (1937, March 25). Het Nieuws van den Dag voor NederlandschIndie. 
Ilyas (2016). Gerakan millenarian Kaiin Bapa Kayah: Protes sosial petani Tangerang 1924 (Thesis UIN Syarif Hidayatullah Jakarta).

Imadudin, I. (2015). “Perlawanan petani di tanah partikelir Tanjoeng oost Batavia tahun 1916". Jurnal Patanjala. 7 (1).

Inlandsch journalist naar Digoel? (1929, April 8). Nieuwe Rotterdamsche Courant.

Iskandar, M. (2007). Aksi kolektif petani Ciomas tahun 1886: Dampak politis bagi pemerintahan Hindia Belanda. Disertasi, Universitas Indonesia.

Itoe kerewelan di tanah Batoe Tjeper. (1934, June 19). Sin Tit Po.

Itoe keriboetan di Batoe Tjeper (Tangerang). (1934, June 21). Bintang Timoer.

Kartodidjo, S.(ed). (1981). Laporan-laporan tentang gerakan protes di Jazwa pada abad XX. Jakarta: ANRI.

Kartodirdjo, S. (1978). Protest movement in rural Java. KualaLumpur: Oxford University Press.

Kartodirdjo, S. (1984). Pemberontakan petani Banten 1888: Kondisi, jalannya peristiwa dan kelanjutannya, sebuah studi kasus mengenai pergerakan sosial di Indonesia. Jakarta: Pustaka jaya.

Kartodirdjo, S. (2005). Sejak Indische sampai Indonesia. Jakarta: Kompas.

Kartodirdjo, S. (ed). (1976). "Memori Residen Batavia (L.G.C.A. van der Hoek), 20 Agustus 1934". Memori serah terima jabatan 1931-1940 Jawa Barat (1). Jakarta: ANRI.

Keriboetan di Batoe Tjeper (Tangerang): Keboeroekan di dalam tanah particulier. (1934, June 11). Bintang Timoer.

Keriboetan di Batoe Tjeper: Sewa tanah dinaikkan 400\%, Pers Putih menghasoet. (1934, June 8). Bintang Yimoer.

Keriboetan di tanah Batoe Tjeper (Tangerang). (1934, June 6). Bintang Timoer.

Kesenian: Toneel opvoering Tirtajasa. (1934, June 13). Bintang Timoer.

Lohanda, M. (1994). The kapitan Cina of Batavia (1834-1942) Jakarta: Djambatan.

Mulyani, A. (2011). Jakarta: Panduan wisata tanpa mal. Jakarta: Gramedia.

Noor,-M. M. (2019). Petani dan pergerakan nasional: Keterlibatan organisasi Tirtajasa dalam kerusuhan di Batu Ceper, 1934 (Master thesis). Universitas Indonesia.

Onghokham (2008). Anti Cina, kapitalisme Cina dan gerakan Cina: Sejarah etnis Cina di Indonesia. Depok: Komunitas Bambu.

Peratoeran baroe atas tanah-tanah particulier di tanah Djawa seblah koelon Tjimangek. Staatsblad 1912, No. 422. Batavia: Landsdrukkerij.

Pokrol-bamboe in de desa. (1913, October 22). Algemeen Handelsblad.

Proces verbaal wedana Tangerang. ANRI: Tangerang Archive No. 106.5.

Rakhmat, J. (1989). Metode penelitian komunikasi, Bandung: Remadja Karya.

Ravando. (2014). Now, it's time to kill Chinesse: Social revolution and the massacre of Chinesse in Tangerang. Thesis, Leiden University.

Regerings almanak voor Nederlandch-Indie 1930. Batavia: Landsrukkerij.

Regerings almanak voor Nederlandsch-Indie 1869. Batavia: Landsrukkerij.

Regerings almanak voor Nederlandsch-Indie 1916. Batavia: Landsrukkerij.

Regerings almanak voor Nederlandsch-Indie 1933. Batavia: Landsrukkerij. 
Reglement omtrent de particuliere landerijen: Geleden ten westen der rivier Tjimanoek. Staatsblad 1836 No. 19. Weltevreden: Boekhandel Visser \& Co Smelser, N. J. (1962). The theory of collective behaviour. New York: The Free Press. Smelser, N. J. (1981). “Collective behaviour \& social movement". Sociology. New Jersey: Prentice Hall.

Tan, Mely G.(ed). (1979). Golongan etnis Tionghoa di Indonesia: Suatu masalah pembinaan kesatuan bangsa. Jakarta: Gramedia.

Tangerang (1910). Topografische Inrichting Batavia. Batavia: Landsrukkerij.

Tirtajasa di dalam tanah Partikelir (Ma'loemat dari Propagandist P.B Tirtajasa). (1934, June 22). Bintang Timoer.

Tjwan, Go Gien. (2008). Desa Dadap: Wujud Bhinneka Tunggal Ika. Jakarta: Elkasa.

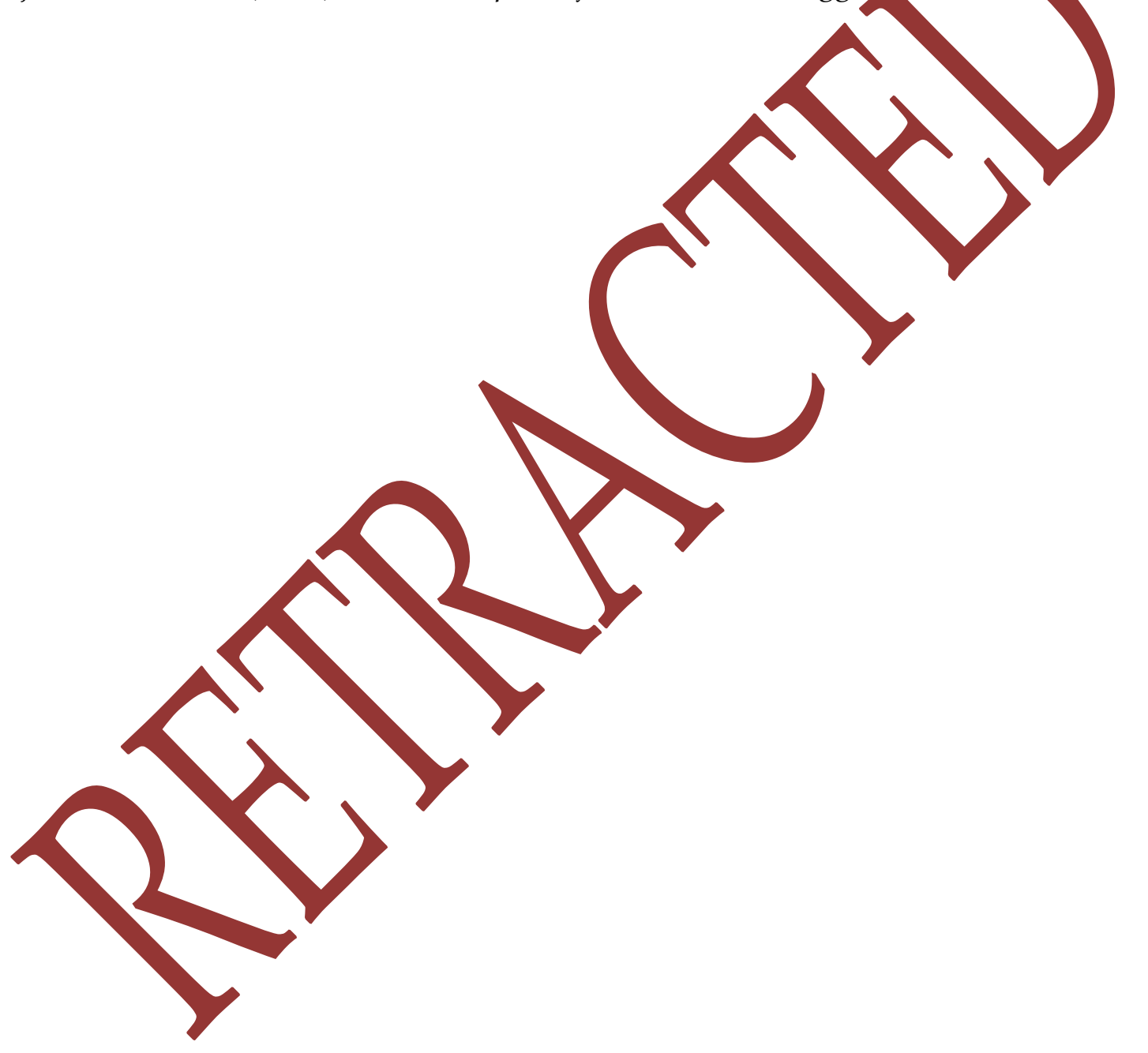

